\title{
Innovation of Legal Education for College Students from the Cultural Perspective
}

\author{
Jue Wang* \\ School of Humanities, Economics and Law \\ Northwestern Polytechnical University \\ Xi’an, China
}

\begin{abstract}
In order to resolve the realistic predicament of unbalanced content, non-interactive method of teaching and weakened consciousness in legal education of Chinese university students at present, with the analytical thinking that the culture is the carrier and the legal system is for application, this paper makes suggestions through analysis of cultural elements in the change of legal system that we should attach great importance to constructing intersubjectivity of cultural subject, making innovations in paradigm of legal education, continuously enriching forms of legal education, clarifying the direction in advocating legal system, strengthening capability in application of laws and emphasizing practice from the perspective of the interactive relationship between culture and law system so as to ultimately achieve the fundamental objective of improving the legal literacy of citizens. The creative conception that this paper brings forth is that this paper integrates legal system into the field of cultural studies and takes a new look the cultural legal system which integrates rationality and morality.
\end{abstract}

Keywords-Culture; Rule of Law; College Students; Legal Education; Cultural Perspective

I. PROBLEMS EXISTING IN CHINA'S COLLEGE LEGAL EDUCATION FROM THE PERSPECTIVE OF CULTURAL RULE OF LAW

\section{A. Lack of Independence and Comprehensive Teaching Content}

Cultural rule of law pursues integration of rationality and morality. In order to enhance college students' all-around development, legal education and moral education should be regarded as equally important. Conversely, in Chinese colleges, moral education has been prioritized over legal education for a long time. More often, legal education is positioned as an attachment to moral education. This deprives legal education of its independence and seriously influences cultivation of students' legal qualities. Currently, the course, "Ideological and Moral Cultivation \& Fundamentals of Law", has been the commonest form of legal education in Chinese colleges. The textbook compiled by the Ministry of Education of the People's Republic of China is made up of "Ideological and Moral Cultivation" by two thirds and "Fundamentals of Law" by one third. Considering the content design, the part of "Fundamentals of Law" introduces different department laws. The knowledge is less systematic, with a combination of basic theories, Constitution, Administrative Law, Civil Law, Economic Law, Criminal Law, Criminal Procedural Law, etc.
Almost the whole legal system of China is covered by this part. However, due to limit of paragraphs, introduction of each law is simple. Usually, only the concepts are given, and in-depth interpretation of institutional value, legal concepts and spirit of rule of law is rare to see. The decreasing proportion of "Fundamentals of Law" seems to deliver a message that legal education is weakening in Chinese colleagues. The sharp cut of teaching hours has also influenced legal education in China. After "Ideological and Moral Cultivation" is combined with "Fundamentals of Law", professors teaching the course often do not have a law education background. Most of them major in moral education. Their unfamiliarity with law theories results in their repeating what the book says. The simple cases they list can hardly inspire students' legal thinking.

\section{B. One-way Cramming Education and Lack of Practicability}

Cultural rule of law emphasizes rational communication. At present, legal education in Chinese colleges is still at the development stage of cramming. On the one hand, the teaching methods of legal education are outdated, which disables legal education to get rid of cramming. Usually, the teacher introduces the knowledge points, and students put down the key points. Even if case study has been introduced to China's legal education, these cases are not updated with passage of time, and the teacher, failing to interpret the cases vividly, cannot effectively capture students' attention. Consequently, legal education is made into a subject which is assessed by rote memorization. On the other hand, the content of legal education is disjointed from practical legal issues college students might encounter. Due to that, students cannot get psychological experience of rule of law, let alone any legal practice.

In China's legal education model for college students, teachers just show students how to abide by law. Without adequate student-teacher interaction, the same legal subjectivity of students and teachers is blurred. It seems the teacher decides all in legal education. The teaching content and schedule are all designed by the teacher. Whether students are interested in the teaching content is often ignored. Consequently, students lose their subjectivity in legal education. Due to lack of interest in legal education, students can hardly be developed with advanced legal qualities. 


\section{Weakening of Subjectivity and Lack of Effectiveness}

In current Chinese colleges, legal education advocates learning of law and standardization of behaviors. The subjectivity of college students is not highlighted. However, "only when every young student becomes an autonomous subject will he or she be willing to be the subject of fulfilling certain responsibility, be held accountable for his or her behaviors, and adjust their behavior to be in line with law" [1]. Subjectivity is also the rationality pursuit of legal education.

China's current college legal education lacks a specific analysis of college students' subjectivity. First, the law majors and the non-law majors are not distinguished from each other. Most colleges do not set up the major of Law. To law majors, their specialized education is legal education. In the university where the author studies, the "Ideological and Moral Cultivation \& Fundamentals of Law" is also offered to law majors. This is obviously a waste of resource, because the law majors are familiar with fundamentals of law. Second, differences of legal education for different subjects are ignored. The professional law knowledge refers to the law knowledge closely related to the major of college students. For example, laws related to journalism, tourism, and environmental protection should be provided for students majoring in Journalism, Tourism Management and Environmental Engineering, respectively. Third, rule of education should be progressive and consider characteristics of college students in different stages. In most Chinese colleges, "Ideological and Moral Cultivation \& Law Fundamentals of Law" is given in the freshman year. After the freshman year, there is almost no legal education. The career guidance provided for college students of a higher grade is of vital importance, because college students' legitimate rights and interests are often seriously violated when they first step into the workplace.

\section{CULTURAL EVOLUTION PROCESS OF RULE OF LAW}

To put it simply, rule of rule is to govern in accordance with law. From the perspective of cultural morphology, evolution of rule of law can be divided into three types, namely political rule of law, economic rule of law, and cultural rule of law. The three types of rule of law are corresponding to three governance stages, namely state-oriented legal governance, individual-oriented legal governance and society-oriented legal governance. Among the three types of rule of law, political rule of law emphasizes identity and will. With political relations as the mainstream form of social interaction and legal system as an effective approach of centralization, political rule of law is regarded as a suppression-oriented form of legal governance. Differently, economic rule of law advocates contractual freedom, equality of trade, supremacy of individual rights, and property safety. In economic rule of law, the legal system is not expected to fully trust public powers. Instead, they are mutually restricted, which results in extensive power separation. Hence, economic rule of law is an objective-oriented form of legal governance. As to cultural rule of law, rational communication, public participation and social welfare are celebrated. Attention is paid to integration between rationality and morality. Rule of law is adopted as a tool to achieve social consensus, forge trust for rule of law among the whole society, develop culture of rule of law, and integrate principles of rule of law into culture.
In this sense, rule of raw turns from institutional governance into cultural governance, which can gain recognition from the governing community easier. Based on the above analysis, it can be seen that rule of law has become not only a ubiquitous form of culture in the human society, but also an irresistible trend of social cultural development. Under the development trend, rule of law gradually evolves into cultural awareness, and a conscious lifestyle built on extensive trust for law. As a form of culture and society, cultural rule of law, transcending political rule of law and economic rule of law, is setting the path for development of China's rule of law. In the foreseeable future, it will also become a general trend of modern civilization.

College is widely regarded as the best site for cultural rule of law. The relationship between college and rule of law can be traced back a long time ago. The first college in the world in the modern sense is the University of Blognia. It was founded with freedom, equality and fairness as its core values, and to popularize law study. Its core values and pursuit formed the soul and cornerstone of colleges set up later. College is a place for cultural inheritance, talent development, scientific research, social service, etc. If a college curbs freedom of ideas and academic research, students' enthusiasm to explore the unknown fields will be dampened. Worse still, innovation and inheritance of ideas and knowledge will be impossible. Only when every student is treated as equals, guaranteed with equal access to opportunities, and allowed to communicate with teachers on an equal basis can more knowledge be explored. Fairness can assure scholars to engage in knowledge innovation without apprehensions. Without doubt, college is leading development of the mainstream social culture. This justifies the feasibility of developing cultural rule of law in colleges first. College students are subjects of colleges. In China, college students are also constructors and successors of socialism with Chinese characteristics. Their cultural awareness and trust for rule of law can largely decide their use of legal thinking and legal solution during their participation in state governance. Moreover, college students' cultural awareness and trust for rule of law have a close bearing on formation of the socialist core values, and finally exert an influence on realization of "China Dream" — a major part of the great rejuvenation of China. Therefore, legal education should be a carrier to foster college students' awareness of cultural subjectivity and spirit of rule of law. Based on problems existing in legal education of Chinese colleges, it has become an imperative to lead students to learn law, respect law and use law, and develop their ability of self-governance and concepts of rights. Continuous innovation of legal education can turn colleges into pilot areas of China's cultural rule of law and frontiers to build a new China ruled by law.

\section{PATHS TO INNOVATE LEGAL EDUCATION FOR COLLEGE STUDENTS FROM THE CULTURAL PERSPECTIVE}

\section{A. Building Intersubjectivity and Enhancing Communication on Legal Education Paradigms}

Intersubjectivity is a core concept of cultural rule of law (society-oriented rule of law) refers to the unity among subjects. The interaction theories formed on the basis propose mutual 
respect for mutual subjectivity among social subjects rather than the negative right confirmation relationship from the perspective of rights and obligations. According to intersubjectivity, subjects should communicate with each other and interact with each other based on principles of mutual help and win-win cooperation. In essence, education is a behavior of interaction or the education process is a process of interaction. Intersubjectivity is included in the behavior of educational interaction. This is also true to legal education. During the process of legal education, the teacher and students are interconnected in terms of their intersubjectivity. They are involved in a new-type teacher-student relationship that pursues democracy, equality, cooperation, interaction, mutual promotion and harmonious coexistence. Construction of subjectivity in legal education can transform the legal education paradigms to intersubjectivity. The educator and the education receivers are no longer engaging in a singledimension teaching activity, but a systematic interaction activity participated by two equal subjects. With cramming education replaced by interactive education, the teacher can better stimulate students to acquire more legal knowledge, strengthen their legal qualities, etc. As to students, they can also challenge the teacher's legal ideas, which raise a higher requirement of the teacher's legal qualities. To promote communication in legal education is to advocate intersubjective equality, and highlight subjectivity of social man. Finally, it will help students develop the legal awareness with equality and freedom as major characteristics.

\section{B. Diversifying Forms of Law Learning and Legal Education Classroom Teaching}

Cultivation of college students' legal qualities is an important link of China's overall legal construction and college students"' quality-oriented education. Evidence has shown that the traditional teaching methods are ineffective. It is time to apply case study, simulated court trial and other innovational teaching methods to legal education classroom teaching. For example, "Law \& Film" can be set up as a public optional course for all students in a college. The course can spark students' interest in learning law by combining vivid images and videos. The scenarios presented by films can also provide more room for students' imagination, deepen their understanding of legal knowledge and methods, and lead them how to solve practical problems using law. This can avoid the boring classroom atmosphere and ineffective teaching caused by traditional teaching methods.

Based on public courses, legal education should be further specified for students of different grades and from different majors. For example, according to students' learning needs, cases related to Internet security and cybercrimes can be integrated in classroom teaching of Computer Science. While providing career guidance for college students of a higher grade, the teacher should enhance their understanding of the Employment Promotion Law, Labor Contract Law, Social Security Law, etc. The focus should be on guiding students to safeguard their legitimate rights and interests during the employment process, and use law to address potential disputes with their prospective employers arising from performance of the labor contract.

\section{Advocating Respect for Law and Popularizing Legal Education Throughout the Campus}

Law is closely connected with life, and can influence every aspect of life and every section of society. To popularize legal education is to let legal education cover the whole learning and living circle of college students, such as the classroom, dormitory, canteen, supermarket, and campus network. This can realize effective combination between the first classroom and the second classroom. Due to logistics socialization reform, college students have been involved in more legal disputes concerning their accommodation, catering, and consumption. Chinese colleges should pay more attention to these disputes, and make good use of different scenarios in the campus to develop students' legal qualities. For example, colleges can popularize the Law on Protection of Consumers' Legitimate Rights and Interests, the Civil Procedural Law, and the Law on Tort Liabilities through the campus broadcasting station, BBS, apartment bulletin, etc. This can enhance students' direct psychological experience, and clarify rights and obligations in the campus life. College administrators should handle students' affairs, teaching affairs and campus development in accordance with law. Meanwhile, they should also standardize their school running and administration behaviors. When any dispute arises, they should settle it impartially, justly and transparently. In this way, a favorable rule of law atmosphere will be created in the campus.

Students' associations in Chinese colleges should contribute their share to popularization of legal education and citizen education via diversified new media. The author thinks that legal education for college students should be integrated into college students' life rather than be infused into their mind mechanically. Some college students report that law is an abstruse subject. Around $69.1 \%$ of college students confess they lack law knowledge [2]. Indeed, the legal clauses are usually highly professional, but college students can learn the legislation spirit and the legal content through more vivid interpretation, demonstration and application. Students' associations, especially Students' Union, should be committed to strengthening college students' understanding of the local rule of law status, legal knowledge and concepts, etc. They can hold a series of educational activities related to law to show that law is a daily existence. Stimulated by these activities, college students will strive to forge correct legal concepts, and build the campus into a place where law is used to handle affairs and settle disputes. The favorable environment of rule of law created in the campus will finally contribute to China's building of a society ruled by law in the real sense.

\section{Honing Students' Legal Qualities and Ability to Use Law}

College is a cultural community, which represents the maturity of social civilization. Cultural rule of law is an objective of China during its development of rule of law, and the objective should first be recognized by college students. Thus, implementation of cultural rule of law in colleges holds vital significance. To fully realize rule of law in China cannot just depend on law professionals. Cultivation of the great masses' legal thinking and awareness to solve problems by law is more important. Law is not just a subject, but also a method 
to solve problems. College students should apply their theoretical law knowledge to daily issues. This will enhance their respect for law, diversify cultural rule of law construction in colleges, and help China get closer to the objective of cultural rule of law. To the end, the author thinks efforts can be made in the following three aspects:

- Encouraging students to adhere to regulate management in self-governance group activities so that they can feel the power of rules in daily learning and life.

- Actively leading students to behave strictly in accordance with their legal rights and obligations, and encouraging them to use law to handle daily issues, and actively get involved in legal practice.

- Giving full play to students' subjectivity by allowing them to participate in campus governance and formulation of campus articles of associations and by promoting democratic consulting so that the campus can be built into a frontier of cultural rule of law construction.

\section{CONCLUSION}

This paper reveals the internal influencing mechanism of the cultural elements in the legal education of Chinese university students, which has great ideological guiding effect on the practice of legal education of university students and provides an important theoretical inspiration for further cultivation of socialist citizens with legal consciousness in the new era. With values at the core, culture can decide people's lifestyle. In the human history, governance of any state cannot be separated from culture. Currently, in China, "rule of law is a basic way of state governance and handling of state affairs" [3].
Thus, state governance should be maintained on the track of rule of law, and the state governance system should be constructed under the rule of law system. To sum up, culture and rule of law are two indispensable parts of state governance. Without culture or rule of law, human civilization progress would have been impossible. Culture and rule of law are interconnected in that culture underlies the essence of rule of law, while rule of law is a phenomenon of culture. Since the essence can decide the phenomenon, cultural development is decisive to development of rule of law. Being a kind of culture, rule of law cannot be realized without the support of cultural elements.

\section{REFERENCES}

[1] Xiong Wei,“Towards a modern legal education for college students," Published in Jiangsu Higher Education, 2009,NO.5. (In Chinese)

[2] Peng Yu. Qin., "New path for contemporary college students' awareness of law--The intersubjectivity style of legal education," Published in China University Students Career Guide, 2012, NO. 4. (In Chinese)

[3] People Press, "Decisions of the Central Committee of the Communist Party of China on Several Major Issues Concerning Comprehensively Deepening Reform,” Beijing: People’s Publishing House, 2013: 38. (In Chinese)

[4] Gong Bin, "The molding of College Students' view of law under the background of ruling by law,” Published in Heilongjiang Researches on Higher Education, 2017,NO.2. (In Chinese)

[5] Wang Chao and Ge Lanning, "To strengthen students' legal education and legal faith,” Published in Law and Society,2017,NO.26. (In Chinese)

[6] Zhang Wenxian, Jurisprudence, Beijing:Higher Education Press,2012. (In Chinese)

[7] Zhang Shumin, "The current situation and existing problems of legal education for college students,” Published in Legal System Exposition,2016,NO.34. (In Chinese) 